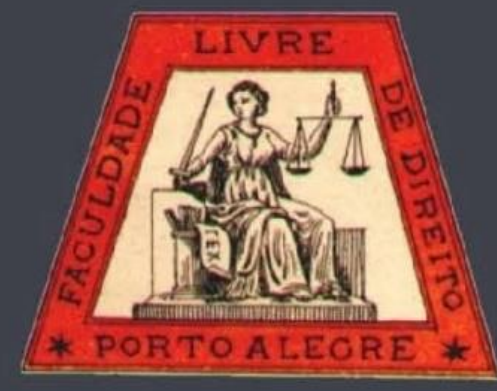

\title{
O processo cautelar sobrevive no Código de Processo Civil de 2015?
}

Does the precautionary process survive in the Civil Procedure Code of 2015?

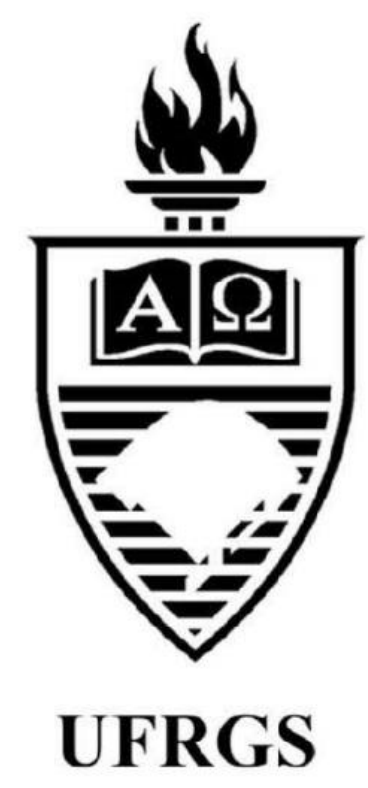

Fabio Resende Leal Instituição Toledo de Ensino

Flávio Luis de Oliveira Universidade Federal do Paraná 


\title{
O processo cautelar sobrevive no Código de Processo Civil de 2015?
}

\author{
Does the precautionary process survive in the Civil Procedure Code of 2015?
}

Fabio Resende Leal ${ }^{*}$

Flávio Luis de Oliveira ${ }^{* *}$

\author{
REFERÊNCIA \\ LEAL, Fabio Resende; OLIVEIRA, Flávio Luis de. O processo cautelar sobrevive no Código de Processo Civil de 2015 ? \\ Revista da Faculdade de Direito da UFRGS, Porto Alegre, n. 38, p. 234-256, ago. 2018.
}

\section{RESUMO}

Este artigo procura desmentir a afirmação, feita em doutrina, de que o processo cautelar desapareceu no Código de Processo Civil de 2015, propondo uma nova forma de definir tal espécie processual. O primeiro de seus cinco itens versa sobre os conceitos de ação e processo; o segundo, sobre os Códigos de Processo Civil de 1939, 1973 e 2015; o terceiro, sobre o sincretismo processual e a tutela cautelar na lei hoje em vigor. Adentrando ao cerne da discussão, o quarto item procura, a partir de situações processuais hipotéticas, demonstrar a possível sobrevivência do processo cautelar, enquanto que o quinto e último, para sustentar tal sobrevida, formula, a título de sugestão, um novo conceito de processo cautelar, a partir da preponderância dos atos preventivos que nele serão praticados, com inspiração em Pontes de Miranda. O método adotado foi pesquisar, além da legislação e sua evolução histórica, os principais autores processuais pátrios em cada um dos três grandes momentos legislativos vividos no Brasil.

\section{PALAVRAS-CHAVE}

Processo cautelar. Sobrevivência. Código de Processo Civil de 2015.

\section{ABSTRACT}

This article seeks to deny the doctrinal assertion that the precautionary process disappeared in the Civil Procedure Code of 2015, proposing a new way of defining that procedural species. The first of its five chapters deals with the concepts of action and process; the second, the Civil Procedure Codes of 1939, 1973 and 2015; the third, procedural syncretism and preliminary injunction in the law today in force. At the heart of the discussion, the fourth chapter seeks, based on hypothetical procedural situations, to demonstrate the possible survival of the precautionary process, while the fifth and last, in order to sustain such survival, formulates, as a suggestion, a new concept of process precautionary, starting from the preponderance of the preventive acts that will be practiced in it, with inspiration in Pontes de Miranda. The method adopted was to investigate, in addition to the legislation and its historical evolution, the main procedural authors of the country in each of the three great legislative moments experienced in Brazil.

\section{KEYWORDS}

Precautionary process. Survival. Code of Civil Procedure of 2015.

\section{SUMÁRIO}

Introdução. 1. Noções conceituais. 2. Escorço histórico. 2.1. Código de Processo Civil de 1939. 2.2. Código de Processo Civil de 1973. 2.3. Código de Processo Civil de 2015. 3. Morte do processo cautelar? 3.1. Sincretismo processual. 3.2. Tutela provisória de urgência cautelar. 4. Sobrevivência do processo cautelar. 4.1. Produção antecipada de prova. 4.2. Pedido de tutela final declaratória prejudicada em razão de autocomposição. 4.3. Atribuição incidental de efeito suspensivo ou ativo a recurso. 5. Preponderância: revisitando o conceito tradicional de processo cautelar. Conclusão. Referências.

\footnotetext{
* Doutorando em Direito pela Instituição Toledo de Ensino de Bauru. Advogado. Professor Adjunto da Universidade Paulista - Campus de Bauru. Coordenador da Comissão OAB vai à Faculdade da OAB/Bauru. Membro do Tribunal de Ética e Disciplina da OAB/SP. Autor do livro A celeridade processual como pressuposto da efetividade dos direitos fundamentais (Curitiba: Juruá, 2011).

** Doutor em Direito pela Universidade Federal do Paraná em 2001. Coordenou o Curso de Graduação em Direito do Centro Universitário de Bauru/SP, mantido pela Instituição Toledo de Ensino - ITE. Advogado.
} 


\section{INTRODUÇÃO}

Algumas verdades, depois de certa ponderação e investigação, acabam por se tornar mentiras ou afirmações parcialmente falsas. Pode ser este o destino de uma das colocações que mais comumente se faz acerca do Código de Processo Civil de 2015. Diz-se, corriqueiramente, que, nesse novo diploma normativo, se extinguiu o processo cautelar tal como o conhecíamos no Código de Processo Civil de 1973. Não mais haveria espaço para um processo cujo objetivo seria apenas garantir a eficácia de outro processo, seja de conhecimento, seja de execução. A tutela cautelar, na sistemática entre nós adotada desde a entrada em vigor do novel código, seria prestada antes ou durante o processo de conhecimento ou de execução. $O$ presente estudo tem como objetivo principal confirmar se, de fato, restou morto o processo cautelar no Código de Processo Civil de 2015.

Para tanto, serão analisados os três Códigos de Processo Civil que vigeram em nosso país, bem como a doutrina de suas respectivas épocas, visando estabelecer, como primeira premissa, o que exatamente deve se entender por processo e, mais especificamente, processo cautelar (itens 1 e 2). Na sequência, será abordando o fenômeno do sincretismo processual e a forma pela qual o código hoje em vigor tratou a tutela cautelar (item 3). Além disso, três situações processuais merecerão abordagem, como forma de demonstrar uma possível sobrevivência do processo cautelar (item 4). Ao final, na tentativa de responder negativamente à hipótese proposta, sugerir-se-á uma forma em parte diferente de conceituar o processo cautelar, a partir da teorização feita por Pontes de Miranda em sua célebre classificação das ações (item 5). O texto se findará com a sintetização de suas principais conclusões.

\section{NOÇÕES CONCEITUAIS}

São quatro os institutos fundamentais do direito processual civil: jurisdição, ação, defesa e processo. Desses, interessam ao presente estudo a ação e, ainda mais, o processo.

A natureza jurídica da ação sempre foi muito debatida. Já se disse que a ação seria o direito de pedir em juízo o que se considerava devido (Savigny). Para Wach, a ação era direito público, concreto e autônomo, com o que, em parte, concordava Chiovenda, mas discordavam Degenkolb e Rocco, segundo os quais a ação era direito autônomo, porém abstrato. Em Liebman, cuja teoria mereceu grande prestígio na academia brasileira, a ação passou a ser considerada como o direito/poder constitucional, subjetivo e instrumental de provocar a jurisdição. Entre nós, parece ter prevalecido o conceito de ação como direito abstrato, autônomo e instrumental ao provimento jurisdicional.

Polêmicas conceituais à parte, para este trabalho, entender-se-á ação como "o direito fundamental de pedir tutela jurisdicional ao Estado-juiz, rompendo a inércia do Poder Judiciário, e de atuar, ao longo do processo, para a obtenção daquele fim" (BUENO, 2017, p. 73). Ao mesmo tempo em que o Estado toma para si a prerrogativa de dirimir os conflitos, vedando a autotutela, assume o dever de prestar adequada e efetiva tutela jurisdicional, ao qual corresponde o direito, assegurado pela Constituição (CF, art. 5. ${ }^{\circ}$,

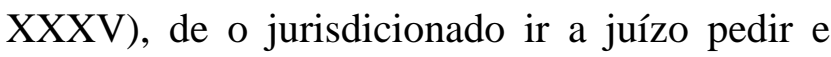
obter tutela jurisdicional. Este é, pois, o direito de ação.

Assim entendido, o direito de ação é uno e invariável. Não temos várias ações. Temos uma única ação. A ação, direito autônomo que é, não está diretamente relacionada ao direito material que se pretende tutelar no processo. Não varia nem se classifica a partir da pretensão de quem a exerce. Ação sempre será ação, e nada mais. A rigor, portanto, é incorreto falar em "ação de conhecimento", "ação de execução", "ação 
cautelar", "ação possessória", “ação de exibição de documentos" etc. Admite-se a utilização de tais expressões apenas em respeito à tradição forense e legislativa de nosso país. O que é variável e admite classificação, a nosso ver, é o processo. ${ }^{1}$

A despeito da discussão, igualmente intrigante, a respeito da natureza jurídica do processo (processo como contrato, situação jurídica, relação jurídica etc.), para os fins aqui perseguidos, convém fixar o conceito de processo como o instrumento pelo qual atua o Estado-juiz no enfrentamento e solução dos conflitos que lhe são levados através do exercício do direito de ação. É, o processo, a forma que o Poder Judiciário tem de dirimir litígios e, consequentemente, prestar tutela jurisdicional; é a ferramenta estatal usada para analisar a demanda e satisfazer o direito material violado ou em vias de o ser.

O processo, ${ }^{2}$ dessa forma, pode ser classificado como processo de conhecimento e processo de execução. Define-se o tipo de processo partindo-se do resultado esperado e da atividade jurisdicional a ser realizada. De conhecimento é o processo que serve para resolver uma "crise de certeza". Nele, o juiz afasta a dúvida e, por sentença, afirma qual das partes merece a providência estipulada pelo direito material. Diferentemente, de execução é o processo que se presta para solucionar uma "crise de inadimplemento", a fim de satisfazer o direito descumprido (DINAMARCO, 2009, p. 153-156). Sob outra ótica, se for preciso analisar fatos e direito para decidir qual das partes tem razão, o processo será de conhecimento. Se, todavia, já houver um direito presumidamente existente, assim reconhecido em título executivo, faltando apenas o adimplemento da obrigação em tal documento estipulada, o processo será de

\footnotetext{
${ }^{1}$ Também admite variação e classificação o procedimento, isto é, o aspecto formal e visível do processo. Em razão da exiguidade do espaço, não se cuidará disso neste artigo.
}

execução. No primeiro, a atividade jurisdicional desenvolvida com maior intensidade é cognitiva (análise das questões de fato ou de direito controvertidas, sobre as quais se espera pronunciamento judicial), ao passo que, no segundo, é executiva (efetivação do direito visando o cumprimento coercitivo de obrigação).

Além desses, o direito processual brasileiro conhece uma terceira espécie de processo, o processo cautelar. Pretendendo o demandante proteger direito processual ou o próprio processo, pedirá em juízo prevenção, isto é, atividade jurisdicional acautelatória, cautelar. O processo cautelar, nesse contexto, é o "acessório" destinado a garantir que o "principal" - processo de conhecimento e/ou de execução possa ser capaz de entregar resultados verdadeiramente úteis. $\mathrm{O}$ processo cautelar não existe por si só; presta-se a permitir que a parte com razão, à luz do direito material, tenha condições de obter a tutela jurisdicional merecida noutro processo, de conhecimento ou de execução. O processo cautelar, assim entendido, se caracteriza pela prática, com maior intensidade, de atos jurisdicionais preventivos.

Uma das várias questões postas com a promulgação do Código de Processo Civil de 2015, que não trouxe um livro ou capítulo destinado ao processo cautelar, é se tal processo sobreviveu no novel código como categoria ou espécie processual própria e distinta dos processos de conhecimento e de execução. É, afinal, a esse questionamento que o presente estudo pretende trazer resposta.

\section{ESCORÇO HISTÓRICO}

Independente de Portugal, o Brasil teve seu processo civil regulado, em um primeiro

${ }^{2} \mathrm{O}$ presente trabalho, como já ressoa óbvio, trata apenas do processo civil, não se preocupando com as demais ramificações do direito processual no que se refere à classificação do processo. 
momento, ainda pelas Ordenações Filipinas (1603) e, depois, pelo Regulamento n. 737 (1850). Foi só em 1939, com o Decreto-Lei n. ${ }^{\circ}$ 1.608, que conheceu seu primeiro Código de Processo Civil, projetado por Pedro Martins Batista e que teve em Francisco Campos, Ministro da Justiça do Estado Novo de Vargas, seu principal artífice. Na sequência, sob a influência da Escola Processual de São Paulo, da qual foi expoente Alfredo Buzaid, Ministro da Justiça na presidência de Jânio Quadros e, em tal condição, responsável pela elaboração do anteprojeto correspondente, veio a lume a Lei n. ${ }^{\circ}$ 5.869/1973, instituidora do Código de Processo Civil que vigoraria de 12 de janeiro de 1974 a 16 de março de 2016. Em 17 de março de 2016, entrou em vigor a Lei n. ${ }^{\circ} 13.105 / 2015$, a qual instituiu o atual Código de Processo Civil, nascido do trabalho da Comissão de Juristas capitaneada por Luiz Fux, hoje Ministro do Supremo Tribunal Federal, a pedido de José Sarney, então Presidente do Senado Federal. Cada qual a seu jeito e modo, todos esses três códigos versaram sobre processo ou, em conformidade com a terminologia adotada pelo último deles, tutela cautelar.

\subsection{Código de Processo Civil de 1939}

O Código de Processo Civil de 1939 era dividido em dez Livros. Os Livros II ("Do Processo em Geral") e III ("Do Processo Ordinário") cuidavam do que hoje conhecemos como visto no item 1 retro - por processo de conhecimento, ou seja, processo voltado à descoberta do direito e para o qual não se reservava rito especial (art. 291). O Livro IV ("Dos Processos Especiais") versava sobre as variações procedimentais do processo de conhecimento ("ação cominatória", "ação de perempção ou preferência”, "ação de consignação em pagamento", "mandado de segurança", "ação de despejo", "ação de depósito", "ações possessórias", "ação de usucapião", "inventário e partilha" etc.), entre as quais se incluíam, com desapego técnico e conceitual, as chamadas "ações executivas", verdadeiros processos de execução, voltados que eram à efetivação do direito, já antecipadamente reconhecido, ao pagamento de importâncias devidas, sob pena de penhora (arts. 298 a 301). Por sua vez, o Livro V ("Dos Processos Acessórios") era reservado a outros procedimentos especiais de processos de conhecimento ("embargos de terceiro", p. ex.), a alguns procedimentos não contenciosos (como, verbi gratia, a restauração de autos) e, no que mais por ora interessa, a processos verdadeiramente cautelares, pois destinados à concessão de medidas cautelares atípicas ("medidas preventivas") e típicas ("depósito preparatório de ação" e "caução", p. ex.).

Com esses processos, visava-se, nas palavras de Amaral Santos, "providências urgentes e provisórias, tendentes a assegurar os efeitos de uma providência principal, em perigo por eventual demora" (1962, p. 212). Neles, podia o juiz "determinar providências para acautelar o interesse das partes", (i) se surgissem "fundados receios de rixa ou violência entre os litigantes"; (ii) fosse, antes da decisão, "provável a ocorrência de atos capazes de causar lesões, de difícil e incerta reparação, no direito de uma das partes"; ou (iii) se, no curso do processo, fosse a uma das partes "impossível produzir prova, por não se achar na posse de determinada coisa" (art. 676). Nesses casos, era facultado ao juiz deferir o arresto de bens do devedor; sequestro de coisa móvel ou imóvel; busca e apreensão, inclusive de mercadorias em trânsito; prestação de cauções; exibição de livro, coisa ou documento; vistorias, arbitramentos e inquirições; obras de conservação em coisa litigiosa; prestação de alimentos provisionais; arrolamento e descrição de bens do casal e dos próprios de cada cônjuge, para servir de base a ulterior inventário, nos casos de desquite, nulidade ou anulação de casamento; 
entrega de objetos ou bens de uso pessoal da mulher e dos filhos (art. 677).

A concessão das "medidas preventivas" justificava-se pela demora processual:

A decisão, no processo de conhecimento, por exigir longa série de atos processuais, demanda tempo comumente não pequeno. A aguardá-la, possivelmente, ao ser proferida, o intêresse [sic] da parte esteja sacrificado. A decisão poderá vir tarde demais. A demora, assim, poderá ser prejudicial à parte. É o que se chama de "periculum in mora". Em razão dêsse [sic] perigo, que poderá acarretar danos enormes à parte, existem as ações cautelares ou preventivas que visam providências jurisdicionais urgentes e provisórias, assecuratórias dos direitos próprios da sentença a ser proferida na ação principal. A justificação dessas providências está, pois, no perigo da demora da sentença a ser proferida no processo principal (SANTOS, 1962, p. 212).

Percebe-se, na lição acima transcrita, os elementos teóricos que viriam, anos depois, a nortear a construção legislativa do processo cautelar no código que substituiu o de 1939.

\subsection{Código de Processo Civil de 1973}

Em suas próprias palavras, Buzaid, conforme coloca em sua Exposição de Motivos, pretendeu "simplificar a estrutura do Código, facilitar-lhe o manejo, racionalizar-lhe o sistema e torná-lo um instrumento dúctil para a administração da justiça” (BRASIL, 1974, p. 8). Era nítida, no então novel código, a preocupação com a celeridade de seus trâmites. Em várias passagens de sua Exposição de Motivos, Buzaid deixou transparecer a preocupação em equilibrar rapidez e justiça, para estruturar um processo efetivamente apto a administrar, sem delongas, a justiça. Foi partindo de tal premissa que o processo cautelar ganhou relevância até então inédita no direito positivo brasileiro (BRASIL, 1974, p. 17).

O Código de Processo Civil de 1973 tinha cinco Livros, dos quais o primeiro cuidava do processo de conhecimento ("Livro I - Do processo de conhecimento") e o segundo, do processo de execução ("Livro II - Do processo de execução"). Ao Livro IV, restou regular os "procedimentos especiais de jurisdição contenciosa" e de "jurisdição voluntária". Do processo cautelar tratava o Livro III ("Do processo cautelar"), o qual se dividia em duas partes, uma voltada a regular os processos de concessão de medidas cautelares inominadas, com base no poder geral de cautela do juiz (arts. 796 a 812), e a outra reservada ao processo de concessão de medidas cautelares nominadas (arts. 813 a 889).

Em nítida evolução, a doutrina da época, ao justificar a existência do processo cautelar, ligava-o à garantia de eficiência da atividade jurisdicional. Não passava despercebida a necessidade de o Estado-juiz se valer de técnicas processuais capazes de contornar os efeitos deletérios do tempo sobre o processo. Certos de que o transcurso do tempo exigido pela tramitação processual poderia acarretar modificações irremediáveis nas coisas, pessoas e relações jurídicas, os processualistas da época pregavam ser indispensável que a tutela a ser prestada pelo Estado fosse "idônea a realizar, em efetivo, o desígnio para o qual foi engendrada" (THEODORO JÚNIOR, 1985, p. 1.104). Isso porque, de acordo com Humberto Theodoro Júnior,

[...] de nada valeria, por exemplo, condenar o obrigado a entregar a coisa devida, se esta já inexistisse ao tempo da sentença; ou garantir à parte o direito de colher um depoimento testemunhal, se a testemunha decisiva já estiver morta quando chegar a fase instrutória do processo; ou, ainda, declarar em sentença o direito à percepção de alimentos a quem, no curso da causa, vier a falecer justamente por carência dos próprios alimentos (1985, p. 1.104).

O processo cautelar, nesses moldes, era a forma de se obter do Poder Judiciário providências práticas - chamadas de "medidas 
cautelares" - que conservassem e assegurassem pessoas, provas e bens.

No entanto, à falta de alternativa, pois não havia na lei previsão para a concessão de medidas de prevenção nos processos de conhecimento e de execução, o processo cautelar acabou servindo também para a outorga do que veio a ser conhecido por "medidas cautelares satisfativas". Eram, então, propostos processos nomeadamente cautelares, mas que, na verdade, pretendiam a obtenção liminar de medidas satisfativas (reconhecimento/satisfação de direito material). A busca e apreensão era uma delas. Embora inicialmente prevista apenas no capítulo destinado aos processos cautelares nominados (CPC/1973, Livro III, Título Único, Capítulo II), acabou sendo largamente admitida a busca e apreensão não como medida assecuratória (cautelar), mas, sim, a depender do caso concreto, como medida satisfativa (não acessória), ${ }^{3}$ a dispensar, por conseguinte, a propositura de outra ação (inaplicabilidade dos arts. 806 e 808, I, do CPC/1973).

\subsection{Código de Processo Civil de 2015}

Certos de que a ausência de celeridade configura ausência de justiça, os membros da comissão encarregada de elaborar o anteprojeto que depois viria a resultar na Lei n. ${ }^{\circ} 13.105 / 2015$, não sem antes sofrer profundas e substanciais mudanças no Senado Federal (PLS n. ${ }^{\circ}$ 166/2010) e na Câmara dos Deputados (PL n. ${ }^{\circ}$ 8.046/2010), elegeram o princípio da razoável duração do processo como o norte a ser perseguido e, conforme consta da Exposição de Motivos, puseram cinco grandes objetivos para a nova norma processual:

\footnotetext{
${ }^{3}$ Nesse sentido, para exemplificar: TJSP, 32. ${ }^{a}$ Câmara de Direito Privado, Apelação sem Revisão n. ${ }^{\circ}$ 1202604-0/6, Rel. Des. Ruy Coppola, j. 19/02/2009.
}

1) estabelecer expressa a implicitamente verdadeira sintonia fina com a Constituição Federal; 2) criar condições para que o juiz possa proferir decisão de forma mais rente à realidade fática subjacente à causa; 3) simplificar, resolvendo problemas e reduzindo a complexidade de subsistemas, como, por exemplo, o recursal; 4) dar todo o rendimento possível a cada processo em si mesmo considerado; e 5) finalmente, sendo talvez este último objetivo parcialmente alcançado pela realização daqueles mencionados antes, imprimir maior grau de organicidade ao sistema, dandolhe, assim, mais coesão (BRASIL, 2010, p. 14).

O código hoje em vigor inovou em relação à estrutura de seu antecessor. Tem ele uma primeira parte, denominada de "Parte Geral", na qual é possível encontrar, positivada, uma verdadeira teoria geral do processo, com princípios e regras atinentes ao processo civil. Essa primeira parte conta com seis livros: "Das normas processuais civis" (arts. 1. a 15); "Da função jurisdicional” (arts. 16 a 69); "Dos sujeitos do processo" (arts. 70 a 187); "Dos atos processuais" (arts. 188 a 293); "Da tutela provisória" (arts. 294 a 311); e "Da formação, da suspensão e da extinção do processo" (arts. 312 a 317). Na sequência, vem a "Parte Especial", com seus quatro livros: "Do processo de conhecimento e do cumprimento de sentença" (arts. 318 a 770); "Do processo de execução" (arts. 771 a 925); "Dos processos nos tribunais e dos meios de impugnação das decisões judiciais" (arts. 926 a 1.044 ); e "Disposições finais e transitórias" (arts. 1.045 a 1.072 ).

Não mais existe livro ou capítulo reservado ao processo cautelar ou às medidas preventivas. A "tutela cautelar" passou a ser tratada como espécie de "tutela provisória de urgência", podendo, em situações extremas, ser requerida e concedida em caráter antecedente, independentemente de um processo específico para tal finalidade. ${ }^{4}$ Daí se falar, na doutrina, em 
extinção do processo cautelar como categoria autônoma de processo civil.

\section{MORTE DO PROCESSO CAUTELAR?}

É, pelo que pudemos apurar, unânime na doutrina o discurso de que o processo cautelar, tal como o conhecíamos enquanto vigente $\mathrm{o}$ revogado código, deixou de existir. A Exposição de Motivos do Anteprojeto do CPC/2015, aliás, fala literalmente em sua extinção:

Extinguiram-se também as ações cautelares nominadas. Adotou-se a regra no sentido de que basta à parte a demonstração do fumus boni iuris e do perigo de ineficácia da prestação jurisdicional para que a providência pleiteada deva ser deferida. Disciplina-se também a tutela sumária que visa a proteger o direito evidente, independentemente de periculum in mora. O Novo CPC agora deixa clara a possibilidade de concessão de tutela de urgência e de tutela à evidência. [...] Ambas essas espécies de tutela vêm disciplinadas na Parte Geral, tendo também desaparecido o livro das Ações Cautelares (BRASIL, 2010, p. 25).

Ninguém nega a sobrevivência, no novo código, da tutela cautelar e de procedimentos destinados à prevenção contra os prejuízos decorrentes da demora processual. Não encontramos, porém, quem falasse na sobrevivência do processo cautelar. No entanto, quer nos parecer que, em situações bastante peculiares, é possível, sim, haver um processo que se caracterize mais pela prática de atos de prevenção do que de cognição e execução. É possível que exista, assim, a despeito da ausência da correspondente previsão legal, um processo o qual se pode alcunhar de cautelar.

A chave para se concordar com essa afirmação passa pela compreensão de que, na nova ordem processual, o processo civil é sincrético e sua conceituação/classificação em espécies ou categorias leva em consideração não apenas a natureza do provimento por ele buscado, mas, principalmente, os atos que em serão nele praticados em maior ou menor número (preponderância), assuntos para os quais se voltarão os subitens seguintes.

\subsection{Sincretismo processual}

$\mathrm{Na}$ redação original do Código de Processo Civil de 1973, não existia um único processo, dividido em fases. Eram três os processos exigidos para a solução de uma mesma lide, um diferindo bastante do outro. Não havia compatibilidade e sistematização. O conjunto era imperfeito, de maneira que a transição de um processo para o outro acabava sendo, obrigatoriamente, lenta e complexa. Perdia-se tempo com a repetição de atos processuais (distribuição, citação, contestação, apelação etc.).

Isso porque, no revogado código, distinguiam-se, por exemplo, o processo de conhecimento com sentença reconhecendo a procedência do pedido de condenação em dinheiro e o processo de execução iniciado justamente para obter o cumprimento de tal condenação, embora ambos tivessem como base a mesma relação jurídica obrigacional (dívida do réu para com o autor). Não bastava a manifestação do Estado-juiz durante e ao final do primeiro de processo (processo cognitivo). Pela sistemática imposta em 1973, era necessário o ajuizamento do segundo processo para se conseguir coagir o réu a cumprir a obrigação que lhe fora imposta pela sentença favorável ao autor (processo executivo). Ou seja, se a pretensão de direito material não estivesse baseada em um título executivo ou não encontrasse amparo em um dos procedimentos especiais do Livro IV ou da legislação complementar, deveria o autor propor seu processo de conhecimento segundo os demorados e complexos trâmites do procedimento comum ordinário do Livro I. Caso a sentença de procedência tivesse conteúdo pecuniário condenatório, o autor daquele primeiro processo cognitivo era obrigado a propor um segundo 
processo, agora executivo, para conseguir ver adimplida a obrigação ou obter o pagamento que merecia em dinheiro.

Ademais, em sendo necessária alguma medida de prevenção, isso somente seria possível através de um terceiro e distinto processo, o cautelar. Não se negava, naquela época, que a jurisdição se realizava pela cognição (definição, como visto no item 1 retro, da vontade concreta da lei diante da situação litigiosa) ou pela execução (efetivação dessa mesma vontade). Mas, a partir do reconhecimento de que, entre a interposição da demanda e a providência satisfativa que dela adviria, o tempo exigido pela tramitação processual poderia acarretar situações irremediáveis, muitas vezes tornando ineficaz ou inútil o processo, se pensou em dotar a atividade jurisdicional de instrumentos e mecanismos adequados para contornar os efeitos deletérios do tempo sobre o processo. Nascia, assim, o processo cautelar, destinado a outorgar situação provisória de segurança, a fim de criar condições para a solução da lide (THEODORO JÚNIOR, 2000, p. 359-361).

Liebman falava em "ação cautelar" (1968, p. 92). Amaral Santos também (1962, p. 212). Nós, pelos motivos expostos no item 1 retro, preferimos falar em "processo cautelar", cujo objetivo principal, senão único, era permitir ao órgão jurisdicional tomar providências práticas - as medidas cautelares - para conservar ou assegurar o processo em si mesmo considerado, eliminando a ameaça de perigo decorrente da demora processual ou o risco de prejuízo ao interesse a ser tutelado em outro processo, de conhecimento ou execução.

A promulgação da Constituição Federal de 1988 mudou radicalmente a forma de encarar, interpretar e aplicar as regras processuais infraconstitucionais. Princípios como o acesso à justiça e o devido processo legal passaram a ser de obrigatória e inequívoca observância. Todavia, o Código de Processo Civil então em vigor demorou a se adequar aos ditames constitucionais e aos anseios da comunidade acadêmica, o que só veio a acontecer a partir de 1994.

Ciente dos graves problemas causados pela maneira como o codex de 1973 tratava o processo, o legislador passou a nele realizar inúmeras reformas, no intuito de melhorá-lo, através da diminuição dos entraves à celeridade processual. Em 1994, a tutela antecipada - ou a antecipação dos efeitos da tutela a ser concedida se procedente o pedido - foi incorporada ao processo de conhecimento (CPC/1973, arts. $273 \mathrm{e}$ 461, na redação dada pela Lei n. ${ }^{\circ}$ 8.952/1994). Passamos, então, a ter a possibilidade de, também no procedimento comum, tutelar a ameaça a direito, dotando de efetividade o comando do artigo 5. ${ }^{\circ}$, inciso XXXV, da Constituição Federal. Vale dizer: ao juiz foi permitida a prática de atos de prevenção, antes reservada aos processos cautelares ou alguns procedimentos especiais, no início e curso do processo de conhecimento que tramitasse pelo procedimento comum.

Além disso, nos anos de 2005 e 2006, em decorrência da Emenda Constitucional n. ${ }^{\circ}$ 45/2004, a Lei n. ${ }^{\circ} 11.232 / 2005$ estabeleceu a fase de cumprimento das sentenças no processo de conhecimento, acabando com a execução por processo autônomo de títulos judiciais. As decisões judiciais ganharam executividade imediata. A sentença não mais simplesmente "extinguia" o processo; quando condenava ao pagamento em pecúnia (obrigação de pagar quantia certa), encerrava a primeira fase do processo e deveria ser cumprida nos mesmos autos (CPC/1973, art. 475-I), sob pena de multa em caso de inadimplemento (CPC/1973, art. 475J).

Por conseguinte, passou a ser possível executar, no curso do processo de conhecimento, a decisão antecipatória de tutela (CPC/1973, com a redação dada pela Lei n. ${ }^{\circ}$ 8.952/1994, arts. 273 e 461) e a sentença condenatória, mesmo antes do trânsito em julgado, cabendo à parte requerer ao 
juiz a tomada de providências para assegurar o adimplemento da obrigação que lhe favorecia. Deixou de ser necessária a ação de execução da obrigação de fazer ou não fazer (CPC/1973, art. 632 e ss.) para que o réu fosse forçado ao adimplemento - ainda que provisório - de tais obrigações. Igualmente, foi facultada a tomada de medidas preventivas, antes reservadas apenas ao processo cautelar (v.g., busca e apreensão ou remoção de pessoas), durante o curso do processo de conhecimento. Não mais era, pois, exigido que o autor ajuizasse ação cautelar incidental para proteger o adimplemento de um direito cujo reconhecimento definitivo só viesse ao final do processo de conhecimento. A intervenção judicial com tal objetivo passou a ser possível no bojo do processo de conhecimento.

Com a execução provisória da tutela antecipada e a prática de atos de prevenção no curso do processo de conhecimento, não mais era exigida a formação de outro processo autuado em apenso e a prática de atos repetitivos. Como o processo e os autos eram um só, era desnecessário despender tempo com inúmeras autuações, certificações, numeração de folhas etc. Bastava uma única citação do réu, o qual, conforme o seu interesse, poderia contestar a pretensão do autor e/ou impugnar as medidas executivas e cautelares por este requeridas/obtidas. As provas, em regra, passaram a ser produzidas em apenas um processo. Os argumentos das partes, além disso, podiam, agora, ser apreciados em uma única sentença. Eventuais discussões sobre as medidas executivas e cautelares passaram a ser dirimidas através de decisão interlocutória, atacáveis via agravo, ao qual não era, via de regra, atribuído efeito suspensivo (CPC/1973, na redação trazida pela Lei n. ${ }^{\circ}$ 9.139/1996, art. 527, II).

A correta utilização desses então novos instrumentos processuais, frutos da fusão, em um único processo, das técnicas de cognição, execução e prevenção, provocou o aceleramento da marcha processual, com a entrega da tutela jurisdicional em tempo mais razoável (= menor). A esse fenômeno a doutrina deu o nome de sincretismo processual. O processo civil, dizia-se em meados da década de 2000 , não pode ser apenas de conhecimento, execução ou cautelar. Nele, a despeito do nome usado, sempre haverá a prática, em maior ou menor grau, de atos cognitivos, executivos e preventivos. Esse processo, portanto, é sincrético, por reunir técnicas - cognição, execução e prevenção - antes tidas por incompatíveis.

Reformado o Código de Processo Civil de 1973, deixou, enfim, de existir um processo típica e exclusivamente de conhecimento. Mesmo se o principal objetivo fosse a descoberta do direito (traço característico do processo dito de conhecimento), nada impedia a prática, neste processo, de atos de execução (característica do processo de execução) ou proteção (processo cautelar). A fase de cumprimento da sentença condenatória é certamente o melhor exemplo de sincretismo processual, pois deixa clara a possibilidade de o processo que começa como cognitivo ("processo de conhecimento") terminar executivo ("processo de execução").

O Código de Processo Civil de 2015, inegavelmente, contemplou o sincretismo processual, não só por manter a execução da decisão condenatória como fase do "processo de conhecimento" (art. 513 e ss.), mas porque adotou a técnica, prevista por seus artigos 305 e 308, através da qual o processo que se inicia com nítida pretensão preventiva se transforma, depois de aditada a petição inicial, para assumir outra feição, cognitiva ou executiva. A tutela preventiva ou cautelar, nesse novo sistema processual, passou a ser requerida e concedida justamente em um processo sincrético. Tanto no processo de conhecimento (art. 318 e ss.) quanto no processo de execução (art. 771 e ss.), é possível pedir e obter tutela cautelar, assunto de que se ocupa o subitem vindouro. 


\subsection{Tutela provisória de urgência cautelar}

A partir do prescreve o Código de Processo Civil de 2015, pode-se distinguir a tutela jurisdicional definitiva (ou, nos dizeres da lei, final) da tutela jurisdicional provisória. Definitiva, do ponto de vista conceitual, é aquela que será prestada ao final das fases cognitiva (reconhecimento do direito) e executiva (satisfação da obrigação) do processo de conhecimento e quando, no processo de execução propriamente dito, se der a satisfação do direito creditório. Provisória, diversamente, é a proteção estatal que pode/deve ser outorgada em momento anterior do processo, não necessariamente precedida de cognição exauriente. Não passou despercebida ao legislador de 2015 a possibilidade de, especialmente em situações emergenciais, por força das quais não é possível ou recomendado esperar o momento reservado à concessão da tutela definitiva, haver um pronunciamento judicial temporário e antecipado, a se caracterizar pela precariedade $\mathrm{e}$ transitoriedade, quase sempre baseado em cognição sumária.

A tutela provisória, por excelência, é baseada na urgência. Aparece naquelas situações onde o perigo de perecimento do direito ou de ineficácia do processo, em decorrência da demora, faz com que se justifique um julgamento sem o aprofundamento que marca a concessão da tutela final. A urgência verificada nos autos permite/exige a imediata tomada de providências, sob pena de depauperamento do direito sub judice ou de inutilidade do próprio processo. Deixa de haver tempo para as ponderações que, a princípio, deveriam preceder a concessão da tutela jurisdicional. O pronunciamento judicial deve ser adiantado e, por isso mesmo, será, a princípio, provisório.

Pelo modelo ao final adotado pelo CPC/2015, a tutela provisória de urgência se subdivide em tutela antecipada e tutela cautelar.
A tutela antecipada é a entrega precipitada do "bem da vida" (ex.: cessação de atividade nociva ao meio-ambiente, retirada de um produto defeituoso do mercado, fornecimento de medicamentos, alimentos provisórios, concessão liminar do mandado de segurança, mandado liminar de reintegração de posse etc.). O pronunciamento que, a rigor, só adviria ao final do processo é antecipado. O direito material é outorgado mais rapidamente àquele que o merece. Quando há, no processo, concessão de tutela antecipada, aquele a quem é favorável decisão nesse sentido acaba por ter sua pretensão satisfeita, ainda que provisoriamente. Pode-se dizer, então, que a decisão antecipatória da tutela é marcada pela satisfatividade.

A tutela cautelar, por sua vez, serve para viabilizar a realização posterior do direito, garantindo - de acordo com a doutrina comumente aceita - a eficiência processual. É ligada à proteção do processo. Serve, pois, para garantir o resultado do processo, seja de conhecimento, seja de execução. A tutela cautelar, a bem da verdade, não se justifica por si mesma. Nenhum litigante quer em juízo apenas a obtenção de uma medida cautelar (ex.: arresto, sequestro, exibição de documentos, atribuição de efeito suspensivo a um recurso com ele não recebido etc.). $\mathrm{O}$ que se quer com o processo é a proteção ou a realização de um determinado direito (ex.: cumprimento da obrigação de pagar, devolução/restituição de coisa, procedência do pedido baseado em fato provado pelo documento exibido, anulação/reforma de decisão em grau de recurso sem que antes haja a correspondente execução provisória etc.). Pede-se a concessão de medida cautelar para garantir que o processo seja capaz de, ao seu fim, verdadeiramente proteger ou realizar o direito material. Não há, com efeito, satisfatividade; mas tão-só cautelaridade.

A tutela cautelar contém pedido próprio, relacionado à proteção do processo cujo resultado útil busca garantir. Esse "pedido cautelar" não se 
confunde com o "pedido principal", a ser apreciado quando da concessão (ou não) da tutela definitiva. Ou, em outras palavras, o requerente deduz dois pedidos, o pedido de tutela final (proteção ou reconhecimento de direito material) e o pedido cautelar (medida cautelar). A tutela cautelar jamais basta por si mesma. Depois de requerida e concedida em caráter antecedente, é, de acordo com a lei, obrigação (rectius: ônus processual) do autor requerer, na sequência, a tutela definitiva, aditando a petição inicial, para nela incluir o "pedido principal" (CPC/2015, art. 308). ${ }^{5-6}$

Por derradeiro, cumpre investigar os requisitos exigidos para a concessão da tutela cautelar. Pela lei hoje em vigor, a outorga da tutela de urgência exige do requerente a demonstração da presença de alguns requisitos. $\mathrm{O}$ primeiro deles é o fumus boni iuris: para a concessão da tutela antecipada e da tutela cautelar, faz-se necessária a demonstração da "probabilidade do direito", aliada a uma narrativa fática verossímil e alicerceada sobre prova convincente. O segundo é o periculum in mora. A concessão da tutela antecipada exige o "perigo de dano", ou seja, perigo de perecimento do direito que se busca proteger ou reconhecer através do processo; a tutela cautelar exige, por suas próprias características e finalidades, outro tipo de urgência, o "risco ao resultado útil do processo". ${ }^{7}$ O que justifica a concessão da tutela

\footnotetext{
${ }^{5}$ A nós, parece que foi em razão dessa distinção que o legislador de 2015 optou pelo tratamento conceitual e procedimental diferenciado para as duas espécies de tutela de urgência. Será antecipada a tutela que, requerida em caráter antecedente (CPC/2015, art. 303), puder se estabilizar (CPC/2015, art. 304), e será cautelar aquela que não contar com a mesma possibilidade, caracterizando-se, pois, pela provisoriedade (apenas eficaz antes e enquanto durar o processo).

${ }^{6}$ Aliás, não passou despercebida do legislador a dificuldade prática de se diferenciar tutela antecipada de tutela cautelar. A opção legislativa para esse problema foi consagrar, tal como feito no velho e reformado código, o princípio da fungibilidade, por força do qual pode ser concedida uma das tutelas de urgência no lugar da outra (CPC/2015, art. 305,
}

cautelar não é o risco de o direito material perecer em razão da demora, mas o risco de o processo se tornar ineficaz pelo transcurso do tempo, não se prestando para tutelar os interesses da parte. A tutela cautelar, assim, serve para garantir eficiência e utilidade ao processo, e não ao direito que se pretende proteger com o processo.

\section{SOBREVIVÊNCIA DO PROCESSO CAUTELAR.}

Não havendo dúvida sobre a conceituação de tutela cautelar, na sistemática do Código de Processo Civil de 1973, era tido por cautelar o processo que se prestava à sua concessão, a fim de garantir que outro processo, de conhecimento ou execução, fosse capaz de ser útil. Pois bem. Algumas situações verificadas após a revogação daquele código talvez nos permitam ver que, ainda hoje, em que pese a falta de previsão legal inequívoca e expressa no Código de Processo Civil de 2015, é possível existir um processo (na acepção mais ampla desse termo) cujo principal, senão único, objetivo é tornar eficaz outro processo, podendo, portanto, ser chamado, quando menos, para fins didáticos ou classificatórios, de processo cautelar.

A antecipação de provas, mesmo sem urgência, é uma dessas situações. Acontecimentos que prejudicam, no curso do processo, a formulação do pedido de tutela final e o

par. ún.). A partir da narrativa fática e legal feita pelo requerente, o juiz, se lhe der razão, concederá a medida mais adequada ao seu sentir, a despeito da nominação ou tipificação usada no requerimento (da mihi factum, dabo tibi jus).

${ }^{7}$ Cumpre-nos registrar, ainda que rapidamente, a existência de entendimento segundo o qual, a despeito da distinção conceitual entre "tutela antecipada" e "tutela cautelar" preservada no CPC/2015, os requisitos para sua concessão foram igualados. Tanto para uma quanto para outra, se exigiria, conforme essa linha de pensar, "a mesma probabilidade do direito além do mesmo perigo de dano ou risco ao resultado útil do processo" (BUENO, 2017, p. 264265 , destacado no original). 
requerimento incidental para que seja emprestado efeito suspensivo ou ativo a recurso são outras duas.

\subsection{Produção antecipada de prova}

A produção antecipada da prova, hoje, está prevista pelos artigos 381 a 383 do Código de Processo Civil de 2015. Será ela admitida em pelo menos três hipóteses: (i) fundado receio de que venha a tornar-se impossível ou muito difícil a verificação de certos fatos na pendência do processo; (ii) a prova a ser produzida antecipadamente pode viabilizar a autocomposição ou outro meio adequado de solução de conflito; e (iii) o prévio conhecimento dos fatos justifica ou evita o ajuizamento de ação.

A primeira dessas hipóteses é a mais comum delas. A prova é produzida antes do momento processual a princípio reservado para tanto (p. ex.: colheita de prova oral em audiência), a fim de se garantir desde logo a confirmação de fato necessária à posterior procedência da pretensão deduzida no processo, afastando-se, com isso, a possibilidade de perda da prova pelo transcurso do tempo (urgência = periculum in mora ou risco ao resultado útil do processo). Exemplo didático é a perícia a ser rapidamente feita em prédio em vias de desabar para comprovar negligência ou imperícia que justificará posterior pedido indenizatório a ser deduzido contra o responsável pela obra.

As duas outras hipóteses espelham exigência doutrinária que veio a ser contemplada pelo legislador de 2015. A antecipação da prova, nessas situações, deixa de ser necessária para evitar o perecimento dos elementos probatórios. Precipita-se a instrução para facilitar a solução do

\footnotetext{
${ }^{8}$ É interessante a ideia defendida por Flávio Luiz Yarshell no sentido de que a prova pode ser vista como elemento através do qual as partes avaliam suas chances, riscos e encargos processuais, de modo a admitir-se a antecipação de sua produção mesmo fora das situações de urgência (2009, p. 137 e 146, entre outras). O ato de instruir, afirma
}

conflito ou mesmo para evitar o processo. ${ }^{8}$ Não há urgência na produção probatória, cuja antecipação se fundamenta na possibilidade de se encontrar elementos fáticos que reduzam a litigiosidade a ponto de as partes se conciliarem ou uma delas considerar inviável processar a outra.

No Código de Processo Civil de 1973, a produção antecipada de provas era formalmente tratada como processo cautelar (arts. 846 a 851), motivo pelo qual a doutrina da época, majoritariamente, a classificava, sim, como processo cautelar. Humberto Theodoro Júnior, usando das palavras de Hugo Simas, afirmou a natureza cautelar da antecipação probatória sob o argumento de que o interesse do requerente "se relaciona apenas com a obtenção, preventiva, da 'documentação do estado de fato que possa vir a influir, de futuro, na instrução de alguma ação'. [...] esse tipo de medida tem efeito acautelatório apenas" (2000, p. 491). Sem negar a natureza cautelar do processo, Vicente Greco Filho lembrava que a produção antecipada de provas não estava sujeita a prazo de caducidade e não perdia sua validade ainda que a ação principal (na sistemática do CPC/1973) não fosse proposta em trinta dias (2009, p. 197).

Havia quem, no entanto, julgasse se tratar de processo de conhecimento, a despeito da terminologia utilizada pelo velho código. Pontes de Miranda fazia um paralelo com a ação proposta principaliter para a declaração da autenticidade ou falsidade de documento (CPC/1973, art. 4. ${ }^{\circ}$, II), ação que "entra formalmente na classe das ações cautelares, mas é declarativa”, e, então, concluía se tratar, a produção antecipada de provas, de ação de conhecimento constitutiva (1976, p. 255-256, destacado no original). Por sua

o processualista em passagem que sucinta seu raciocínio, "pode ser visto não apenas como abrangente de meios para preparar o julgamento estatal, mas como meio de esclarecimento e de convencimento das partes para eventualmente se evitar o processo declaratório e a decisão estatal imperativa" (2009, p. 147). 
vez, Flávio Luiz Yarshell, na tese com a qual conquistou a titularidade como professor de direito processual civil na Universidade de São Paulo, depois publicada como livro, defendeu a "natureza constitutiva (positiva)" da produção antecipada de provas:

[...] uma vez exercitado o poder estatal, o resultado consistente na prova produzida é algo que se impõe às partes - e, a rigor, ao próprio Estado - como um fenômeno consumado, ainda que ela possa ser futuramente repetida ou até mesmo desconsiderada. [...] Por outras palavras, uma vez que a prova seja produzida, a realidade está modificada (2009, p. 313 e 314$).$

A discussão permanece com o novo código. A produção antecipada de provas no Código de Processo Civil de 2015 tem ou não natureza cautelar? Pode ela, ainda hoje, ser considerada medida cautelar? Parece haver na doutrina produzida desde a publicação da Lei n. $^{\circ}$ 13.105/2015 certo consenso quanto à perda, pela antecipação de provas, de sua natureza de cautelar, especialmente em se considerando o teor dos incisos II e III do artigo 381 (produção antecipada de prova sem o requisito urgência). Nesse sentido, apenas para citar poucos exemplos, se tem o escólio de Daniel Amorim Assumpção Neves (2015, p. 276) e José Miguel Garcia Medina (2016, p. 638). Olavo de Oliveira Neto, Elias Marques de Medeiros Neto e Patrícia Elias Cozzolino de Oliveira concordam quanto à inexistência de natureza cautelar e consideram se tratar de "ação de conhecimento, de natureza declaratória, que visa antecipar o momento adequado da produção da prova":

[...] realizada a colheita da prova, restará ao magistrado proferir sentença que declare que a produção se realizou em consonância com o procedimento previsto para a sua realização, o que se limita, em última análise, a certificar a legalidade da prova produzida de forma antecipada (2016, p. 253).

O problema dessa colocação, em que pese a qualidade acadêmica de quem a fez, está no fato de que, depois de produzida a prova, não haverá outra decisão ou pronunciamento judicial (CPC/2015, art. 382, § 2. ${ }^{\circ}$ ). O juiz, vindo a prova aos autos, sobre ela nesse momento não exarará juízo de valor algum. Não se pronunciará sobre a ocorrência ou a inocorrência do fato, nem sobre as respectivas consequências jurídicas; no máximo, autorizará a retirada dos autos físicos de cartório ou secretaria pelo promovente (CPC/2015, art. 383, par. ún.), providência para a qual, aliás, nem mesmo se exige despacho, bastando ato meramente ordinatório (CPC/2015, art. 203, $\left.\S 4 .^{\circ}\right)$. De modo que a definição da natureza do processo que tem a precipitação da instrução como finalidade deve levar em consideração o único verdadeiro provimento judicial a ser feito, vale dizer, a decisão que defere, ou não, a produção antecipada.

Partindo dessa premissa e considerando que haverá análise de mérito por parte do juiz, no mínimo, quanto à presença ou ausência dos requisitos que permitem a antecipação de provas (NEVES, 2008, p. 221), não se pode negar a prática de atividade judicial cognitiva a esse respeito. Portanto, quando do deferimento ou indeferimento do pedido de precipitação da instrução, o pronunciamento judicial se reveste de características que o aproximam dos pronunciamentos feitos nos processos de conhecimento. Além disso, é possível se ver, nessa decisão, eficácia declaratória e constitutiva. O juiz que defere a produção antecipada de provas reconhece e declara o direito do requerente a tal providência e, depois, como consequência lógica, autoriza a instrução pretendida, permitindo, com isso, a criação de elementos probatórios a serem futuramente aproveitados. Pode haver, ademais, carga condenatória, seja para condenar o requerido a colaborar com a produção da prova (com base, p. ex., no CPC/2015, arts. 396 e 473, $\S 3 .^{\circ}$ ), seja para condenar o perdedor nos ônus da sucumbência (CPC/2015, arts. 82, § 2. ${ }^{\circ}$, e 85). 
Tudo isso, no entanto, não é suficiente para caracterizar o processo antecipatório de provas como processo preponderantemente cognitivo. $\mathrm{Na}$ verdade, malgrado as opiniões em contrário, a antecipação de provas não deixa de ter natureza cautelar nem naquelas situações em que é deferida independentemente da urgência, pois sempre será acessória, instrumental; jamais bastará por si só. A instrução preventiva, portanto, continua sendo medida cautelar, e o processo que a tem como objetivo principal outro nome não pode receber senão processo cautelar - ou melhor, na linha do que será exposto no item 5 infra, processo preponderantemente cautelar.

É claro que, nesse processo, haverá cognição e, talvez, até execução. Não será deferido o pedido, se o juiz não se convencer da presença dos requisitos autorizadores, realizando, para tanto, óbvia atividade cognitiva, antes da qual, como regra, deverá ser assegurado o contraditório (CPC/2015, arts. 9. ${ }^{\circ}$, caput, e 382, § $1^{\circ}{ }^{\circ}$ ). O sincretismo, entretanto, não é suficiente como visto no subitem 3.1 retro - para não chamarmos de cautelar esse processo. $\mathrm{O}$ processo que visa exclusivamente obter instrução preventiva não tem características que, preponderantes, poderiam lhe trazer a alcunha de processo de conhecimento. Falta-lhe lide (conflito de interesses qualificado pela pretensão resistida) a espera de solução. Quando o decide, o juiz não diz qual é o direito a ser aplicado na solução de um conflito de interesses subjetivos, que, aliás, provavelmente sequer ainda existe ou foi judicialmente estabelecido. Não se trata, pois, de atividade cognitiva em grau e intensidade tal que permitisse a caracterização do processo em questão como processo de conhecimento. No ato decisório, o foco é a presença, ou não, dos requisitos que autorizam a precipitação da prova, medida nitidamente instrumental (= cautelar). A atividade jurisdicional almejada

é preponderantemente preventiva, pois serve para garantir a obtenção de um resultado útil (sentença de mérito, acordo, análise da viabilidade da pretensão sob a ótica do direito material etc.).

Dito isso, é possível, conceitualmente, enquadrar a produção antecipada de provas requerida conforme o artigo 381, inciso I, do Código de Processo Civil de 2015, cujo deferimento exige urgência e posterior aproveitamento da prova, como processo e/ou medida cautelar, porque, com a antecipação da instrução, o que quer a parte é ter em seu favor provas ("meio") que, no futuro, lhe permitirão ter êxito no processo ("fim").

Será, a nosso ver, cautelar também a produção antecipada de provas requerida nos termos dos demais incisos do citado artigo 381 (viabilização da autocomposição ou outro meio adequado de solução de conflito e prévio conhecimento dos fatos para justificar ou evitar o ajuizamento de ação). É certo que, aqui, não se cogita da urgência, mas nem por isso deixa a medida postulada (instrução preventiva) de ter como escopo a garantia ou confirmação de algo, ou seja, do acordo, da viabilidade da ação, do êxito na solução da lide etc. Continua, assim, a produção antecipada de prova sendo "meio", e não "fim". 9 "Fim" será o acordo, a viabilidade da ação, o êxito na solução da lide etc. Certamente, no mundo real, ninguém irá a juízo apenas para provar determinada circunstância fática. Provar só para provar não interessa a ninguém. Almejase provar a ocorrência de um fato para, na sequência, ter algum ganho - mesmo que isso signifique não propor ação fadada ao fracasso à vista da prova antes produzida. Sempre haverá, assim, algo a mais do que a mera produção antecipada de provas; sempre haverá algo a ser prevenido ou garantido com ela.

\footnotetext{
${ }^{9}$ É possível se falar, com apoio na doutrina, em permanente instrumentalidade da prova, a qual, "ainda que produzida antecipadamente e constituindo ela própria o objeto de dado
} 
Do inciso II do dispositivo legal ora em exame, se tira a possibilidade de se antecipar a produção probatória como tentativa "de viabilizar a autocomposição ou outro meio adequado de solução de conflito". Pode-se, então, pensar nela como forma de obtenção dos elementos de prova ("meio") a serem a posteriori utilizados na conciliação, mediação ou arbitragem ("fim"). A propósito, lembre-se que, "Antes de instituída a arbitragem, as partes poderão recorrer ao Poder Judiciário para a concessão de medida cautelar [...]" (Lei n. ${ }^{\circ}$ 9.307/1996, art. 22-A), como a produção antecipada de provas. A instrução preventiva, nesse caso, outra natureza não tem senão a de uma medida cautelar, pois servirá urge destacar - para viabilizar (= garantir, possibilitar) a autocomposição ou a heterocomposição arbitral.

O mesmo raciocínio serve à hipótese prevista pelo inciso III, na qual se antecipa, pela instrução preventiva, o prévio conhecimento dos fatos ("meio") com o intuito de justificar ou evitar o ajuizamento de ação ("fim"). Também aqui se tem medida preventiva, a se caracterizar não pela satisfatividade, mas pela cautelaridade. Conhecendo os fatos com antecedência, o requerente se convence, antes do início do processo, sobre a viabilidade ou não de levar sua pretensão a juízo (prognóstico quanto às suas reais chances de sucesso). Dessa forma, ele se garante, se acautela. A produção antecipada de provas, mesmo nessa situação, tem características de medida cautelar.

\subsection{Pedido de tutela final declaratória prejudicado em razão da autocomposição}

Pela sistemática esquematizada na Lei n. ${ }^{\circ} 13.105 / 2015$, ao invés dos dois processos distintos do velho código, em um único feito deverão ser reunidos os pedidos de tutela final e de tutela cautelar, servindo esta, justamente, para permitir que haja condições de ser aquela concedida de maneira efetiva e útil. Nas situações verdadeiramente urgentes, é possível ao autor requerer a princípio apenas a tutela cautelar (CPC/2015, art. 305), cabendo-lhe, na sequência, aditar a petição inicial para nela incluir o pedido de tutela final (CPC/2015, art. 308). É esse pedido de tutela final que, no mais das vezes, vai permitir a classificação do processo (classificação quanto à providência jurisdicional postulada). Se almejar o autor a práticas de atos de execução com base em título executivo, o processo será de execução. Do contrário, será de conhecimento.

No entanto, a depender da evolução do processo, o pedido de tutela final sequer será formulado, não havendo, por conseguinte, nem execução nem cognição exauriente. A atividade jurisdicional realizada com maior intensidade terá sido, então, preventiva. Esse processo - cabe a pergunta - pode ser classificado como cautelar, já que a única providência postulada e concedida pelo Estado-juiz foi, na verdade, preventiva (= cautelar)?

Para ilustrar, podemos pensar em uma das mais corriqueiras situações vivenciadas nos fóruns pátrios, o pedido (cautelar) de sustação de protesto antecedente ao pedido (final) de declaração de inexigibilidade da obrigação/dívida. Imaginemos que, embora tivesse a devedora (uma empresa de bom nome comercial na praça) realizado, na forma contratada, o pagamento parcial da quantia devida, a credora enviou para protesto título no qual constava a integralidade da dívida. Temerosa de que a efetivação do protesto pudesse lhe trazer prejuízos, diante do presumível abalo que sua reputação sofreria, e com pouco tempo para preparar a petição inicial, pois em três dias o protesto seria lavrado, a devedora optou por, incialmente, pedir em juízo apenas a sustação do protesto, medida que, a seu ver, serviria, primeiro, para evitar os temidos danos e, segundo e mais importante, garantir que a procedência do pedido de tutela final (declaração de inexigibilidade 
parcial do débito) fosse capaz de lhe trazer resultados verdadeiramente uteis, já que sua reputação ficaria preservada até lá (tutela cautelar requerida em caráter antecedente $=\mathrm{CPC} / 2015$, art. 305). ${ }^{10}$ Deferida e executada a liminar, o protesto foi sustado. Porém, antes de a autora aditar a petição inicial, incluindo o pedido de tutela final (prolação de sentença que, se não obtida composição em audiência tornasse definitivo o provimento cautelar inicial, reconhecesse $\mathrm{o}$ pagamento feito $\mathrm{e}$, principalmente, declarasse a inexigibilidade parcial da obrigação de pagar, condenando a ré nos ônus da sucumbência), a ré, citada (CPC/2015, art. 306), extrajudicialmente reconheceu o erro e concordou em receber apenas a parte faltante, retirando, por conseguinte, do cartório o título apontado para protesto. As partes, nesses termos, se compuseram e o acordo foi homologado por sentença (CPC/2015, art. 487, III, "b"). Por fim, a ré retirou o título do cartório e a autora pagou a quantia remanescente, tendo o acordo sido, dessa maneira, cumprido integral e tempestivamente.

Nesse caso, a concessão e efetivação do que seria, em tese, apenas uma tutela cautelar preparatória/antecedente (a sustação do protesto) se mostrou, na prática, suficiente para que as partes chegassem à autocomposição, tornando prejudicado o pedido de tutela final e, via de consequência, desnecessário o prosseguimento do processo em conformidade com o que a fria letra da lei prevê (CPC/2015, art. 308). Mesmo sem o aditamento da exordial, jamais se cogitou da perda de eficácia da decisão cautelar (CPC/2015, art. 309, I), pois o resultado primordialmente buscado pela jurisdição - a solução da lide - veio

\footnotetext{
${ }^{10}$ Embora comumente tida por medida cautelar, a sustação pode, às vezes, assumir caráter satisfativo. Não obstante, no caso hipotético ora desenhado, por ocasião da confecção e distribuição da exordial, era primordialmente forma de garantir que o processo então iniciado fosse capaz de permitir que a autora chegasse com sua reputação comercial ilibada até o momento de concessão da tutela final
}

a ser alcançado pelo acordo. Portanto, os efeitos concretos da tutela cautelar - sustação do protesto e consequente manutenção do bom nome comercial da autora - se tornaram permanentes sob o ponto de vista temporal. Era um pedido cautelar, mas que veio a se mostrar, depois de concedido, portador de qualidades que o aproximam de um pedido de tutela definitiva.

Considerando o desfecho do processo e o único pedido nele feito, bem como a desnecessidade de intervenção estatal para dirimir o conflito entre as partes (característica mais marcante dos processos de conhecimento) e a ausência de cognição exauriente acerca das questões de fundo, é possível classificar tal processo como processo cautelar. Servem, aqui, as tradicionais colocações feitas pela doutrina há mais de cinquenta anos quanto à classificação dos processos a partir da providência jurisdicional pretendida: será cautelar o processo que objetivar a concessão de tutela preventiva, visando acautelar interesse em perigo por conta da demora processual (SANTOS, 1962, p. 204) - exatamente como aconteceu na situação ora estudada.

\subsection{Atribuição incidental de efeito suspensivo ou ativo a recurso}

De acordo com o Código de Processo Civil de 2015, a apelação é interposta perante o juízo sentenciante, mas sua admissibilidade fica a cargo do tribunal, ao qual compete seu recebimento e processamento (art. 1.010, § 3. ${ }^{\circ}$ ). Assim, não há deliberação por parte do órgão $a$ quo acerca dos efeitos com os quais referido recurso é recebido. A decisão a esse respeito compete ao órgão ad quem, na pessoa do

pretendida (sentença que, reconhecendo o pagamento que fizera, declarasse inexigível a parte quitada da dívida). Tinha, pois, viés cautelar, e não satisfativo. Sustar o protesto não era o verdadeiro objetivo; a autoria almejava que, afastado o risco de dano decorrente do protesto, fosse declarado o parcial pagamento que realizara. 
desembargador relator (art. 1.012, § 3. ${ }^{\circ}$, II). Contudo, muitas vezes, não há condições de se esperar o trâmite processual exigido entre a interposição da apelação e sua posterior distribuição (arts. 1.010 e 1.011). A suspensão da eficácia da sentença (efeito suspensivo) ou a antecipação da tutela recursal (efeito ativo) talvez não possam esperar, por haver risco de dano grave ou de difícil reparação (periculum in mora).

Imaginemos que a sentença rejeita $o$ pedido formulado pelo autor (pessoa pobre e doente), para que o réu (Estado) lhe bancasse cirurgia urgente de alto custo. Com sua vida em risco, certamente o autor não poderia esperar a regular distribuição de sua apelação no tribunal, para, só então, postular junto ao relator a tutela de urgência que lhe fora negada em primeira instância (CPC/2015, art. 932, II). A situação fática exige pronta intervenção do Judiciário. Mesmo com os autos ("autos principais") ainda em primeira instância, para o oferecimento de contrarrazões (CPC/2015, art. 1.011, § 1. $\left.{ }^{\circ}\right)$, já pode o apelante requerer diretamente ao tribunal a antecipação do resultado esperado de sua apelação. Para tanto, deverá ele dirigir ao presidente da corte pedido de tutela de urgência, demonstrando a solidez de sua pretensão (fumus boni iuris) e a necessidade de pronta intervenção (periculum in mora), nos termos dos artigos 299, parágrafo único, e 300 do vigente Código de Processo Civil. Para a apreciação desse pedido urgente, haverá o sorteio de um desembargador relator, o qual se tornará depois prevento para o processamento e julgamento da apelação, quando da chegada dos autos ao tribunal (CPC/2015, art. $1.012, \S 3 .^{\circ}$, por analogia).

Não deve ser difícil perceber que, nesse caso, a utilidade do processo para o autor/apelante só existirá se, antes do julgamento da apelação, lhe for dada a oportunidade de deduzir pedido de tutela de urgência, pedido este de natureza satisfativa (tutela antecipada). Não obstante, o incidente processual que, no tribunal (onde será autuado e numerado = "autos assessórios"), terá tal finalidade (antecipação da tutela recursal, com a consequente autorização para que ocorra a cirurgia à custa do réu/apelado) reveste-se de características que o aproximam bastante do antigo processo cautelar incidental, já que seu escopo é justamente garantir a efetividade e a utilidade do processo cognitivo que, no exemplo ora analisado, está aguardando o desenlace de formalidades ainda em primeira instância. Em outras palavras, a despeito de não podermos falar, a rigor, em processo, pois na verdade o que se tem é mero incidente, embora autuado em apartado e com numeração própria, não é desprezível que, assim formatado, referido incidente venha a ser tipificado, a partir da tutela que nele é requerida (antecipação do resultado da apelação com vistas a dar utilidade ao processo cognitivo = atividade jurisdicional preventiva), como cautelar (no sentido de acessório, acautelatório, preventivo, garantidor do resultado esperado no processo de conhecimento, este, sim, o "processo principal”).

O mesmo vale para o procedimento de atribuição de efeito suspensivo à apelação antes de sua distribuição (CPC/2015, art. 1.012, §§ 1. ${ }^{\circ}$, 3. e $\left.4 .^{\circ}\right)$. Enquanto os "autos principais" aguardam sua remessa ao tribunal, será instaurado na segunda instância incidente processual, com autuação e numeração própria, cujo objetivo será - a exemplo da antiga "ação cautelar incidental" - a concessão de uma medida preventiva, apta a impedir que o apelante sofra prejuízos graves ou de difícil reparação por conta da execução provisória da sentença. A concessão do efeito suspensivo à apelação, nesse contexto, pode ser vista como tutela cautelar, por ser capaz de remover os riscos que a execução do julgado trará. Ao emprestar efeito suspensivo ao recurso, conforme lhe requereu incidentalmente $\mathrm{o}$ recorrente, o desembargador relator terá praticado ato processual de prevenção; terá, dizendo de outro modo, concedido medida que, na prática, servirá para afastar o risco de prejuízo ao 
processo. Salvo engano nosso, nessa hipótese, ainda que - outra vez - não se trate exatamente de processo, o incidente em questão se caracterizará muito mais pela cautelaridade, do que pela satisfatividade. Será, pois, cautelar, e não cognitivo ou executivo.

\section{PREPONDERÂNCIA: REVISITANDO O CONCEITO TRADICIONAL DE PROCESSO CAUTELAR}

A despeito do sincretismo sobre o qual falamos no subitem 3.1 retro, pensando em facilitar a compreensão e o uso do direito processual no dia-a-dia forense, sob os pontos de vista conceitual e de técnica legislativa, julgamos correto, ainda hoje, o uso das expressões "processo de conhecimento" e "processo de execução". Existe o processo de conhecimento e existe o processo de execução, cada qual com suas características e peculiaridades. Tanto em um quanto no outro, haverá a prática de atos cognitivos, executivos e preventivos. Não obstante, o processo receberá o nome e seguirá as respectivas regras legais conforme os atos que nele preponderarem, isto é, forem realizados em maior número e com maior intensidade do que os demais.

A ideia da preponderância não é nova. Chiovenda e, no Brasil, Amaral Santos entendiam haver "ações com predominante função executiva", nas quais predominava a função executiva, embora não deixassem de ter também função declaratória, como, verbi gratia, as ações cominatórias, ações de despejo e ações de depósito (1962, p 213-214). Pontes de Miranda trabalhou o conceito, a fim de criticar a

\footnotetext{
11 “A ação somente é declaratória porque sua eficácia maior é a de declarar. Ação declaratória é a ação predominantemente declaratória. Mais se quer que se declare do que se mande, do que se constitua, do que se condene, do que se execute. [...] A ação somente é constitutiva porque sua carga maior é a de constitutividade. Ação constitutiva é a ação predominantemente constitutiva. [...] A ação somente é condenatória porque
}

classificação ternária das ações (ações declaratória, constitutiva e condenatória). Depois de demonstrar a existência autônoma das ações mandamental e executiva (1970, p. 117-122), dizia ele inexistir ação ou sentença pura. Nenhuma seria apenas declaratória, constitutiva ou condenatória. Nem apenas mandamental ou apenas executiva. Todas têm, em maior ou menor grau (ou peso), carga declaratória, constitutiva, condenatória, mandamental ou executiva (1970, p. 122-124). Na perspectiva ponteana, a carga preponderante é que daria nome à ação. ${ }^{11}$

Partindo daí como inspiração, podemos dizer que o processo delineado pelo Livro I da Parte Especial do Código de Processo Civil de 2015 é "processo de conhecimento" - ou, com maior apuro técnico, processo preponderantemente de conhecimento, pois, nele haverá mais cognição, mas com espaço para técnicas e atos antes reservados aos processos nomeados executivo (execução $=$ astreintes, $\mathrm{p}$. ex.) e cautelar (prevenção = concessão de medida inaudita altera parte, p. ex.). Igualmente, será "processo de execução" ou processo preponderantemente de execução o previsto pelo Livro II da Parte Especial, marcado pela realização com maior intensidade dos atos executivos. E "processo cautelar" ou processo preponderantemente cautelar aquele que, como os exemplos citados no item anterior, apresentar, com maior força, a prática de atos de prevenção, destinados estes a assegurar não direito material, mas a eficiência e utilidade do processo.

Convém destacar, antes de terminar, que esse processo preponderantemente cautelar, muitas vezes, poderá prescindir da urgência; caracterizar-se-á, mais, pela instrumentalidade do

preponderantemente o é. Ação condenatória é a ação preponderantemente condenatória. Mais se pede condenar do que declarar, do que executar, do que constituir, do que mandar. [...] A ação somente é mandamental porque preponderantemente o é. [...] A ação executiva é a ação preponderantemente executiva (1972, 124-125, destacouse). 
provimento que através dele será buscado. Servirá, pois, para a obtenção de medida preventiva e acessória cuja finalidade é buscar algo diferente da satisfação ou execução; seu escopo principal será dotar outro processo de eficácia, possibilitar a autocomposição ou, até, justificar a não propositura de ação litigiosa.

\section{CONCLUSÃO}

Existe, sim, um processo preponderantemente cautelar, que se caracteriza e, via de consequência, é conceituado/nominado pela prática, em maior número e intensidade, de atos preventivos. A cognição e a execução, nesse processo, são técnicas secundárias. Nele, o que a parte verdadeiramente quer é a realização de atividade preventiva, acautelatória, com vistas a garantir, no mais das vezes, a eficiência e a utilidade processual. Esse processo cautelar tem como mister principal buscar algo diferente da satisfação ou da execução. Seu objetivo primordial é trazer eficácia para outro processo, podendo, excepcionalmente, possibilitar medida que permita a autocomposição ou justifique a não propositura de ação litigiosa.

A despeito do pouco tempo de vigência da Lei n. $^{\circ} 13.105 / 2015$, a praxe forense já mostrou a possibilidade de a pretensão inicialmente apenas cautelar (CPC/2015, art. 305), depois de atendida, tornar desnecessário o prosseguimento do processo (CPC/2015, art. 308), o qual terminará sem cognição exauriente e muito menos execução, tendo, na prática, servido somente para a realização de atos de prevenção, atos estes que deveriam ser, assim se pensava no início do feito, meramente instrumentais e de eficácia pretensamente provisória, mas que acabaram por proporcionar resultados duradouros.

Também já se nota possível e, quiçá, justificada a existência de um processo autônomo (ou, pelo menos, de um incidente processual autônomo) cujo objetivo é garantir o resultado de outro processo, como acontece, verbi gratia, na veiculação de pedido de suspensão da eficácia da decisão diretamente ao tribunal competente para julgar o recurso, hipótese na qual, estando os autos no órgão a quo, far-se-á necessário dar início a outro feito (ou incidente) junto ao órgão ad quem. Nesses dois casos, estaremos diante não de um processo de conhecimento ou de execução, mas de um processo preponderantemente cautelar, porque acessório e instrumental.

Em conclusão, pode-se dizer que, mesmo tendo sido suprimido textualmente do Código de Processo Civil de 2015, o processo cautelar ainda sobrevive entre nós, ao lado dos processos de conhecimento e de execução, como espécie processual autônoma, a merecer, portanto, tratamento e estudo diferenciado. 


\section{REFERÊNCIAS}

BUENO, Cassio Scarpinella. Manual de direito processual civil. 3. ed. São Paulo: Saraiva, 2017.

BRASIL. Decreto-lei n. ${ }^{\circ}$ 1.608, de 18 de setembro de 1939. Disponível em: <http://www.planalto.gov.br/ccivil_03/decreto-lei/1937-1946/Del1608.htm>. Acesso em 16 jul. 2017.

BRASIL. Lei n. ${ }^{\circ}$ 5.869, de 11 de janeiro de 1973. Disponível em: <http://www.planalto.gov.br/ccivil_03/leis/L5869.htm>. Acesso em 16 jul. 2017.

BRASIL. Código de processo civil: histórico da lei. Brasília: Senado Federal, Subsecretaria de Edições Técnicas, $1974 . \quad$ v. 1 , t. 1 , p. 1-188. Disponível em: <http://www2.senado.leg.br/bdsf/handle/id/177828>. Acesso em 17 jul. 2017.

BRASIL. Constituição Federal. Disponível em: <http://www.planalto.gov.br/ccivil_03/constituicao/constituicao.htm>. Acesso em: 7 jul. 2017.

BRASIL. Anteprojeto do Novo Código de Processo Civil. Brasília, 2010. Disponível em: <https://www.senado.gov.br/senado/novocpc/pdf/Anteprojeto.pdf>. Acesso em 17 jul. 2017.

BRASIL. Lei n. ${ }^{\circ}$ 13.105, de 16 de março de 2015 . Disponível em: <http://www.planalto.gov.br/ccivil_03/leis/L9868.htm>. Acesso em: 7 jul. 2017.

CAPPELlETTI, Mauro; GARTH, Bryant. Acesso à justiça. Porto Alegre: Sergio Antonio Fabris, 1988.

CINTRA, Antônio Carlos de; GRINOVER, Ada Pellegrini. Teoria geral do processo. 13. ed. São Paulo: Malheiros, 1997.

DINAMARCO, Cândido Rangel. A instrumentalidade do processo. 2. ed. São Paulo: Revista dos Tribunais, 1990.

DINAMARCO, Cândido Rangel. Instituições de direito processual civil. 6. ed. São Paulo: Malheiros, 2009. Volume 1.

FADEL, Sergio Sahione. Código de Processo Civil comentado. Rio de Janeiro: José Konfino, 1974. Tomo 4.

GRECO FILHO, Vicente. Direito processual civil brasileiro. 20. ed. São Paulo: Saraiva, 2009. Volume 3.

LEAL, Fabio Resende. A celeridade processual como pressuposto da efetividade dos direitos fundamentais. Curitiba: Juruá, 2011.

LEAL, Fabio Resende. A sobrevivência do processo cautelar no Código de Processo Civil de 2015. In: I Simpósio Brasileiro de Processo Civil da Academia Brasileira De Direito Constitucional, 2017, Curitiba. 
LOPES, João Batista. Tutela antecipada. 3. ed. São Paulo: Revista dos Tribunais, 2007.

MEDINA, José Miguel Garcia. Direito processual civil moderno. 2. ed. São Paulo: Revista dos Tribunais, 2016.

MIRANDA, Pontes de. Tratado das ações. São Paulo: Revista dos Tribunais, 1970. Tomo 1.

MIRANDA, Pontes de. Comentários ao Código de Processo Civil. Rio de Janeiro: Forense, 1976. Tomo 7.

NEVES, Daniel Amorim Assumpção. Ações probatórias autônomas. São Paulo: Saraiva, 2008.

NEVES, Daniel Amorim Assumpção. Novo CPC. Rio de Janeiro: Forense, 2015.

OLIVEIRA, Flávio Luís de. A antecipação da tutela dos alimentos provisórios e provisionais cumulados à ação de investigação de paternidade. São Paulo: Malheiros, 1999.

OLIVEIRA NETO, Olavo de; MEDEIROS NETO, Elias Marques de; OLIVEIRA, Patrícia Elias Cozzolino de. Curso de direito processual civil. São Paulo: Verbatim, 2016. Volume 2.

PODETTI, Ramiro J. Tratado de las medidas cautelares. Buenos Aires: Ediar, 1956.

SANTOS, Moacyr Amaral. Primeiras linhas de direito processual civil. São Paulo: Max Limonad, 1962. Volume 1.

THEODORO JÚNIOR, Humberto. Curso de direito processual civil. Rio de Janeiro: Forense, 1985. Volume 2.

THEODORO JÚNIOR, Humberto. Curso de direito processual civil. 27. ed. Rio de Janeiro: Forense, 2000. Volume 2.

THEODORO JÚNIOR, Humberto. Curso de direito processual civil. 57. ed. Rio de Janeiro: Forense, 2016. Volume 1.

YARSHELL, Flávio Luiz. Antecipação da prova sem o requisito da urgência e direito autônomo à prova. São Paulo: Malheiros, 2009.

Recebido em: 29/09/2017

Aceito em: 27/11/2017 
